\title{
Fabrication Of Gold Nanoparticles In Absence Of Surfactant As In Vitro Carrier Of Plasmid DNA
}

This article was published in the following Dove Press journal:

International Journal of Nanomedicine

\author{
Rania S Abdel-Rashid (D) \\ Samia M Omar ${ }^{1,2}$ \\ Mohammed S Teiama' \\ Ahmed Khairy ${ }^{3}$ \\ Mohamed Magdy (ID) \\ Badawi Anis (iD) \\ 'Department of Pharmaceutics, Faculty of \\ Pharmacy, Helwan University, Cairo, \\ Egypt; ${ }^{2}$ Department of Pharmaceutics, \\ Faculty of Pharmacy, Ahram Canadian \\ University, Giza, Egypt; ${ }^{3}$ Department of \\ Pharmaceutics, National Organization for \\ Drug Control and Research (NODCAR), \\ Cairo, Egypt; ${ }^{4}$ Ministry of Interior, \\ Administration of Criminal Evidence, \\ Cairo, Egypt; ${ }^{5}$ Spectroscopy Department, \\ Physics Division, National Research \\ Centre, Giza, Egypt
}

Purpose: This work aimed to synthesize surfactant-free AuNPs for targeted delivery of plasmid DNA encoded p53 gene and to avoid conventional production method of Gold nanoparticles (AuNPs) which may adversely affect the final shape, diversity, and size due to accumulation of the formulated surfactant - gold complex to the surface.

Methods: The AuNPs were fabricated using seeded-growth method with L-Cystine methyl ester hydrochloride as capping agent, then loaded with plasmid DNA encoded p53 gene. The resultant AuNPs and AuNPs-p53 complex were evaluated for physical characteristics and morphology. Confirmation of complex formation was performed using gel electrophoresis. Furthermore, the efficient delivery and cytotoxicity behavior of the encoded gene were examined on both healthy lung cells (WI38) and cancerous lung cells (A549).

Results: L-cysteine methyl ester hydrochloride AuNPs showed acceptable physical characteristics $(30 \mathrm{~nm},+36.9 \mathrm{mv}$, and spherical morphology). P53 attachment to AuNPs was confirmed by gel electrophoresis. The RT-PCR proved the overexpression of p53 by the fabricated AuNPs-p53 complex. The high percentage of cell viability in normal lung cell line (WI 38) proved the safety of L-cysteine methyl ester functionalized AuNPs. Additionally, the apoptotic effect due to expression of p53 gene loaded on AuNPs was only prominent in lung cancer cell line (A549), revealing selectivity and targeting efficiency of anticancer AuNPsp53 complex.

Conclusion: AuNPs can be considered as a potential delivery system for effective transfection of plasmid DNA which can be used for successful treatment of cancer.

Keywords: gold nanoparticles, plasmid DNA, human lung cancer, transfection, gene delivery

\section{Introduction}

Improving cancer medications is perceived as a necessary need for drug designers, academic analysts, and financing bodies. Chemotherapy is the foremost approach for treating different types of cancer; however, the disease prognosis is affected by resistance of cancer cells to chemotherapy and radiotherapy, and the individual patient's improvement according to the protocol and stage of cancer that control cancer metastasis. ${ }^{1}$ Nowadays, the activation of important silent genes or knocking down of deviated gene inside cancer cells or cancer stem cells has become one of the most promising approaches in cancer treatment. ${ }^{2,3}$

The defect and deviation in behavior of protein 53 (p53) was observed clearly with many types of human cancer. Therefore, the genetically-encoded p53 protein; the tumor suppressor, was suspected to show an extraordinary importance in cancer development and treatment. ${ }^{4}$ P53 gene controls most of the vital functions of cells
Correspondence: Rania S Abdel-Rashid Pharmacy, Helwan University, Ain Helwan, Cairo II795, Egypt

Tel +201156995596

Fax +2025553487

Email sansoova@yahoo.com 
like cell apoptosis, digestion system, cell cycle and cell cycle arrest. ${ }^{5-7}$ In expansion, p53 is specifically enrolled to the mitochondria and actuates apoptosis free of its work. ${ }^{8}$ When a normal human cell loses the routine activity of p53 as a result of sudden mutation or gene deletion, it fails to arrange different vital processes such as cell death and growth. Consequently, the cell changes its nature, stops the apoptosis program, and becomes eternized cancer cell. ${ }^{9}$ Although the role of p53 in tumor suppression was established in different types of cancer, new released data from scientific communities confirmed its important role in cancer treatment through handling levels of reactive oxygen species (ROS), controlling digestion system, and improvement of autophagy. ${ }^{9-11}$ However, using p53 in cancer therapy has been limited due to lack of efficient delivery to the target mal-functioning organ. Therefore, the complexation of p53 with different types of nanoparticles has been strongly suggested for efficient cellular uptake of p53. ${ }^{12}$ The recent studies in nanomaterials and polymer engineering reported a great turning point in the field of nanoscale delivery. It overcomes many of non-viral vectors' drawbacks by increasing their loading efficiency, tissue targeting, and passing of biological barriers. ${ }^{13}$ Nowadays, inorganic nanomaterials appear widely in different research and studies due to their unique optical and electrical characteristics, ease of preparation, low in-vivo toxicity, and biocompatibility. Among these inorganic nanomaterials, silver, graphene oxide, gold, and calcium phosphate are considered for biomedical efficiency. ${ }^{14,15}$ Gold nanoparticles (AuNPs) were broadly utilized in different fields like immunoassays, clinical chemistry ${ }^{16}$ biosensors,${ }^{17}$ monitoring of cells and tissues, ${ }^{18}$ and optical imaging. ${ }^{19}$ The synthesized gold nanoparticles (AuNPs) are formed with an inert, toxic-free and biocompatible core, with high capability to connect with and enter cells, so it may be favored as a starting material for carrier construction. ${ }^{16,18}$ In spite of the fact that AuNPs are multifunctional, a number of problems are still present with this type of nanoparticle like toxicity of fabricated particles, as well as the in vitro and in vivo efficiency due to utilization of harmful chemicals and surfactants. ${ }^{20}$ Thus, this work aimed to synthesize surfactant-free AuNPs for targeted delivery of plasmid DNA encoded p53 gene, and to evaluate their influence on in vitro cytotoxicity and transfection efficiency of p53 gene. The importance of this work lies in gaining both the advantage of powerful apoptotic effect of p53 and AuNPs which already have cytotoxic properties without hazards of using surfactant.

\section{Materials And Methods}

\section{Materials}

Plasmid DNA (pcDNA3 p53 WT) was kindly donated by David Meek (Addgene plasmid \#69003). Chloride salt of gold (III) $\left(\mathrm{AuCl}_{3}\right)$, sodium borohydride $\left(\mathrm{NaBH}_{4}\right)$, hydroxylammonium chloride $\left(\mathrm{HONH}_{2} \cdot \mathrm{HCl}\right)$, Dimethyl sulfoxide (DMSO), and L-Cysteine methyl ester hydrochloride $98 \% \quad\left(\mathrm{H}_{5} \mathrm{CH}_{2} \mathrm{CH}\left[\mathrm{NH}_{2}\right] \mathrm{COOCH}_{3} \cdot \mathrm{HCl}\right)$ were purchased from Sigma Aldrich Co. (St Louis, MO, USA). Highly purified water was used as a solvent. Healthy lung cells (WI38) and cancerous lung cells (A549) were obtained from Cell Culture laboratory-VACSERA-EGYPT. RPMI $1640,10 \%$ fetal calf serum were obtained from Biowhittaker-Belgium. RPMI 1640, minimum essential medium with Earle's salts (E-MEM) from GIBCO-USA, nonessential amino acids and $1 \mathrm{mM}$ Sodium Pyruvate 100 $\mathrm{U} / \mathrm{mL}$ Penicillin, $100 \mu \mathrm{g} / \mathrm{mL}$ Streptomycin, L-Glutamine, and $2.5 \mathrm{mcg} / \mathrm{mL}$ Amphotericin B solution were purchased from CellGro, Inc. VA, USA.

\section{Preparation Of Gold Nanoparticles (Au NPs) L-Cysteine Seeds}

Gold nanoparticles were fabricated according to previously reported method that was initiated by Guo group in 2015 with certain modification. ${ }^{21}$ The present study employed only L- cysteine methyl ester hydrochloride as capping agent without any other surface-active agents or chemicals. Briefly, the original seeds were prepared by the addition of $0.5 \mathrm{mmol} \mathrm{L}^{-1}$ from the aqueous solution of gold chloride $(77 \mathrm{~mL})$ to a $0.5 \mathrm{mmol}$ of $\mathrm{L}^{-1} \mathrm{~L}$-cysteine methyl ester hydrochloride solution $(0.75 \mathrm{~mL})$ and the mixture was stirred for $2000 \mathrm{rpm}$ (200 rpm x 10 mins) at room temperature. After that, ice cold solution of $144 \mathrm{mmol} \mathrm{L}^{-1} \mathrm{NaBH}_{4}(0.27 \mathrm{~mL})$ was added to the previous contents resulting in instantaneous color change into dark brown from faint yellow. One hour later, the obtained AuNPs-L-cysteine seeds were used as Seeds (GR1) for the next step.

Seed-mediated growth method was utilized in presence of hydroxylammonium chloride as reducing agent for the sake of optimization of different generations of AuNPs ${ }^{21-23}$ Fifty mL of $\mathrm{AuCl}_{3}\left(0.5 \mathrm{mmol} \mathrm{L}^{-1}\right), 0.49 \mathrm{~mL}$ of a $51.6 \mathrm{mmol} \mathrm{L}^{-1}$ L-cysteine methyl ester hydrochloride solution and different volumes of the colloidal seeds' solution were added together, then the mixture was stirred gently followed by addition of $0.33 \mathrm{~mL}$ of $115.8 \mathrm{mmol} \mathrm{L}^{-1}$ hydroxylamine hydrochloride and stirring for 6 hrs. 


\section{Characterization Of Gold Nanoparticles (AuNPs)}

Ultraviolet-Visible Spectroscopy

The fabrication of gold nanoparticles was preliminary confirmed by using the specific surface resonance band of plasmon around $530 \mathrm{~nm}$ which was achieved with a Jenway 6305 spectrophotometer with a Xenon lamp (1 $\mathrm{nm}$ resolution, 200-1000 $\mathrm{nm}$ range, UK). Moreover, the prepared colloid gold nanoparticles were stored at $4^{\circ} \mathrm{C}$ for 90 days (vials protected from light) and the obtained spectra from stored colloids were compared with freshly prepared one for qualitative evaluation of samples' stability. ${ }^{24}$

\section{Measurement Of Particle Size And Surface Zeta Potential}

The particle size, surface zeta potential, and polydispersity index (PDI) of colloid gold nanoparticles were measured, using dynamic light scattering Malvern Instruments, Zeta Sizer Nano-series (Nano ZS, UK). Highly purified deionized water was used to dilute all samples before all steps of measurements at normal room temperature. Each sample was measured three times, and was represented after calculation of standard deviation (sample reading $\pm \mathrm{SD}$ ).

\section{Sample Imaging With TEM (Transmission Electron Microscopy)}

The prepared nanoparticles were placed on copper network coated with carbon and kept for drying overnight in air, prior to inspection of sample morphology with a JEOL JEM-2100 TEM operating at $200 \mathrm{kV}$.

\section{Production And Purification Of pDNA Encoded P53 Gene}

The gene DNA3 p53 was amplified in a cell culture of $E$. coli DH5-Alpha. The bacteria was incubated at $37^{\circ} \mathrm{C}$ overnight in Luria-Bertani culture medium supported with 100 $\mu \mathrm{g} / \mathrm{mL}$ of ampicillin. ${ }^{25}$ Cells were collected by centrifugation and the plasmid was purified by kit-free alkaline lysis plasmid miniprep. The concentration of collected purified pDNA was estimated using spectrophotometrical technique to measure the density by determination of absorption at $260 \mathrm{~nm}$ using the standard equation:

$$
\begin{aligned}
\text { concentration }(\mu \mathrm{g} / \mathrm{mL})= & \text { Optical Density } 260 \times 50 \\
& x \text { practical dilution factor }
\end{aligned}
$$

The purity of obtained DNA was confirmed by calculating the $\mathrm{OD}_{260} / \mathrm{OD}_{280}$ ratio.

\section{Preparation Of Au NPs-P53 Complex}

A certain volume of AuNPs colloidal solution was added into a p53 solution, with ratio 1:2 followed by incubation and gentle shaking at room temperature for six hours. The mass ratio (1:2 of AuNPs to p53) was selected based on preliminary studies (data not shown).

\section{Agarose Gel Electrophoresis}

Gel retardation (electrophoresis) was implemented to verify complex formation. Ladder, free plasmid, and AuNPsp53 complex were loaded onto $1 \%(\mathrm{w} / \mathrm{v})$ agarose gel in Tris buffer. The run was applied for $30 \mathrm{~min}$ at $120 \mathrm{~V}$ and the resulting data were imaged with UV camera. ${ }^{26}$

\section{Characterization Of Au NPs-P53 Complex}

The colloidal AuNPs-p53 complex was characterized for its particle size, zeta potential, and morphology at the same conditions previously described in section 2.3 .

\section{Cell Culture And Treatment}

For the sake of reaching full conception of the transfection efficiency of the formulated Au NPs-p53 complex, a comparison between a normal cell line (WI-38) and cancer cell line (A549) was conducted. Cancerous lung cells (A549) were cultured in RPMI 1640 medium while healthy lung cells (WI38) were maintained in E-MEM culture medium. Both media were supplemented with $10 \%$ FBS (fetal bovine serum), $1 \%$ L-glutamine, and $1 \%$ antibiotic-antimycotic mixture $(10,000 \mathrm{U} / \mathrm{mL}$ potassium penicillin, $10,000 \mu \mathrm{g} / \mathrm{mL}$ streptomycin sulphate and $25 \mu \mathrm{g} / \mathrm{mL}$ amphotericin B). ${ }^{27}$

\section{In Vitro Transfection Study}

After completion of cell seeding and attachment, the lung cancer Cell line A549 media were gently discarded. A 200 $\mu \mathrm{L}$ of different solution of AuNp/p53 complex, and free plasmid were dispensed into three replicates, and then incubated at body temperature for two consecutive cycles in 96-well plate. The first incubation cycle was for $4 \mathrm{hrs}$, followed by second cycle for 24 hrs after replacement of media with new one. The transfection efficiency was evaluated by quantification of the level of mRNA transcription for p53 gene by RT-PCR. For the sake of comparison, healthy cell line (WI-38) was used as standard as it normally contains pDNA encoded gene p53. 


\section{Gene Expression By RT-PCR}

RT-PCR was carried out to estimate the expression of p53 level alone and in AuNP-p53 complex using RT-PCR kit (Life Technologies, Thermo Fisher Scientific, Waltham, MA, USA). In the reaction tube, $25 \mu \mathrm{L}$ of $2 \mathrm{X}$ SYBR ${ }^{\circledR}$ Green RTPCR Reaction Mix was added. Then, $1.5 \mu \mathrm{L}$ of forward primer $(10 \mu \mathrm{M})\left(\mathrm{p} 53 \mathrm{~F}: 5^{\prime}\right.$ - CCCCTCCTGGCCCCTGTCATCTTC$\left.3^{\prime}\right)$ and $1.5 \mu \mathrm{L}$ of reverse primer $(10 \mu \mathrm{M})\left(\mathrm{p} 53 \mathrm{R}: 5^{\prime}-\right.$ GCAGCGCCTCACAACCTCCGTCAT-3'). Seventeen $\mu \mathrm{L}$ of RNase free water was added, and the samples were denatured for $3-5$ mins at $95^{\circ} \mathrm{C}$. Magnification step was processed through $30 \mathrm{sec}$ cycle 35 times, with annealing at $57^{\circ} \mathrm{C}$, and extension at $72^{\circ} \mathrm{C}$ for $45 \mathrm{sec}$. Finally, samples were exposed to heating at $72^{\circ} \mathrm{C}$ for $5 \mathrm{~min}$; then the reaction was terminated. ${ }^{28}$ A housekeeping gene ( $ß$-actin) was also included to normalize the gene levels before analysis.

\section{In Vitro Cytotoxicity}

Cytotoxic effects of AuNPs on both A549 and WI-38 cell lines were determined using MTT assay. Pre-cultured 96-well plates were treated with serial concentrations of obtained AuNPs and AuNP.p53 complex for $24 \mathrm{hrs}$ at $37^{\circ} \mathrm{C}$. Treated cell lines were microscopically examined using Cell culture inverted microscope (Hund - Germany) to follow the morphological changes and cell growth. When cells nearly covered the bottom of the plates, dead cells were washed-out with a mixture of PBS (phosphate buffer saline) containing $0.05 \%$ Tween. Media were aspirated and $25 \mu \mathrm{L}$ of $0.5 \%$ MTT solution was added in dark conditions and incubated for $3-4$ hrs at $37^{\circ} \mathrm{C}$. MTT formazan crystals were dissolved on a plate and gentle shaking was performed for 30 mins (Stuart - England). Optical densities (OD) were read using (Biotek - 8000, USA) ELISA plate reader. Viability percentage was calculated as follows: ${ }^{29}$

$$
\begin{aligned}
\text { Viability } \%= & =\text { optical density of sample } / \\
& \text { optical density of control }) \times 100
\end{aligned}
$$

Results represent average of 3 independent repetitions with 3 replicates for both AuNPs and AuNPs-p53 with two cell lines, A549 and WI-38. Results were used for calculation of $\mathrm{IC}_{50}$ at the previous conditions.

\section{Statistical Analysis}

In order to evaluate the statistical significance of the obtained results and for the sake of comparison, Student's $t$-test was used to compare averages of obtained results. Statistical significance was set at $\mathrm{P}<0.05$. Lower and upper fiducial limits were also determined at $95 \%$ confidence interval.

\section{Results And Discussion \\ Preparation And Characterization Of AuNPs}

The results showed the ability of production of AuNPs in the presence of a suitable capping agent such as L-Cysteine methyl hydrochloride ester, which agreed with previously published results. ${ }^{27}$ L-Cysteine ester is expected to anchor to the gold depending on the mercapto group (-SH) which exhibits a great affinity to gold metal, allowing anchoring of cysteine to the nanoparticles. The study was able to avoid using nonspecific cytotoxicity and uncontrolled cell death triggered by cetyltrimethylammonium bromide (CTAB). ${ }^{30}$

\section{Ultraviolet-Visible Spectroscopy}

Ultraviolet-visible spectrum of AuNPs prepared using L-cysteine methyl ester hydrochloride as capping agent was represented in Figure 1. The prepared AuNPs solution had a wine red colour. The figure confirms the fabrication of gold nanoparticles by showing clear characteristic bands of plasmon at $K_{\max } 532 \mathrm{~nm}$ of the freshly prepared GR 5 AuNPs scanning. This peak coincides with the characteristic peak of gold nanoparticles in literature reports. ${ }^{31,32}$ The UV-visible spectroscopy could not detect a clear plasmon band for AuNPs from GR 1 and GR 2, which may suggest ultrasmall size. ${ }^{21,33}$ Figure 1 also confirms the stability of the stored samples of gold nanoparticles. Whereas, UV-Vis absorption spectra from freshly prepared gold nanoparticles and samples that were stored for 90 days revealed slight difference in the maximum of resonance bands $\left(K_{\max }\right.$ 539-532 nm), and there was no evidence of degradation or appearance of new peaks. The slight shift in the plasmon

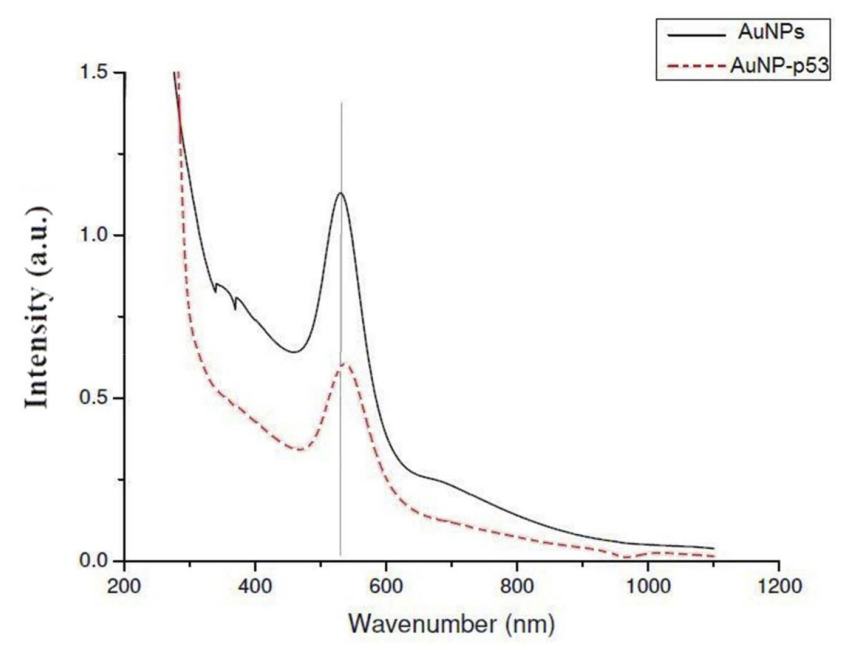

Figure I UV.VIS absorption spectra for freshly prepared AuNPs (GR5) compared to the same sample after 90 days' storage at $4^{\circ} \mathrm{C}$ in a dark room. 
band absorption could be attributed to increase in effect of surface functionalization of AuNPs which may cause slight elevation of value of local refractive index at the surface of stored gold nanoparticles. ${ }^{34}$ The band intensity is very sensitive to any change in $\mathrm{pH}$ of the medium and increase in cysteine surface capping which may occur during storage which may be changed during storage. ${ }^{35}$ The previous results propose the suitability of the fabrication method and offer a qualitative stability of the obtained gold nanoparticles.

\section{Measurements Of Particle Size And Surface Zeta Potential}

In this study, chloride gold III solution (a precursor) was used rather than $\mathrm{HAuCl}_{4}$ solution to avoid elevation of the acidity of the aqueous solution which would affect the fabrication process and the gold particle size. ${ }^{21}$ At the first seed growth GR1, seeds exhibited a mean diameter around $1.8 \mathrm{~nm}$, as shown in Table 1. This small particle size may be due to reduction of $\mathrm{AuCl}_{3}$ solution with ice-cold $\mathrm{NaBH}_{4}$ in the presence of L-cystine ester. Successive seed growth method using L-cysteine methyl ester was applied to synthesize positively-charged spherical gold nanoparticles. Further surface reduction of gold chloride III was performed in the presence of Au-L-cysteine methyl ester seeds with hydroxylammonium chloride. This step produced samples of GR2 to GR5 with mean diameters between 7-30 $\mathrm{nm}$ (Table 1). The proportional increase in particle size of gold nano-seeds could be clarified by the successive ripening manner of the gold nano-seeds. ${ }^{21,36,37}$

The results encouraged the ending of successive seedmediated growth after reaching GR5. This decision was based on reports that revealed further seed-mediated growth may lead to significant increase in particle size which may not favor complex formation and cellular uptake process. $^{38,39}$ Guo et al (2015) formed AuNPs that reached $195 \mathrm{~nm}$ at GR12. ${ }^{21}$ Past studies have shown that cellular uptake of AuNPs may be changed depending on molecular size. Moreover, it was also the suitable particle

Table I DLS Characterization Of AuNPs

\begin{tabular}{|l|l|l|l|}
\hline $\begin{array}{l}\text { Seeds } \\
\text { Growth } \\
\text { Number }\end{array}$ & $\begin{array}{l}\text { Particle Size } \\
\pm \text { SD (nm) }\end{array}$ & PDI \pm SD & $\begin{array}{l}\text { Zeta Potential } \\
\pm \text { SD (mv) }\end{array}$ \\
\hline GR I & $1.8 \pm 0.2$ & $0.632 \pm 0.04$ & $+35.4 \pm 3.5$ \\
GR 2 & $6.9 \pm 0.4$ & $0.543 \pm 0.04$ & $+33.8 \pm 4.0$ \\
GR 3 & $11.6 \pm 0.3$ & $0.354 \pm 0.01$ & $+36.7 \pm 2.7$ \\
GR 4 & $18.3 \pm 0.9$ & $0.401 \pm 0.02$ & $+35.8 \pm 3.1$ \\
GR 5 & $30 \pm 1.5$ & $0.321 \pm 0.01$ & $+36.9 \pm 2.9$ \\
\hline
\end{tabular}

size of AuNPs for cell internalization, ranging from 2-40 nm. ${ }^{38-42}$ Furthermore, it was recommended to use AuNPs of median size to insure higher cellular uptake, especially after complexing with DNA molecules. ${ }^{41}$

The PDI of the prepared AuNPs ranged between 0.30.6 as shown in Table 1, where GR5 showed the lowest PDI value.

The zeta potential measurements were also demonstrated in Table 1. The zeta potential showed positive charge for all AuNPs solutions. This could be attributed to the functionalization of gold nanoparticles with L-cysteine methyl ester which contains an ammonium group $(-\mathrm{NH} 3+)$, due to free hydrogen ions that adhere to amine group in acidic aqueous media. This positive charge is essential to the stability of the colloidal nanogold solution and complex formation with pDNA via electrostatic attachment.

Basing on the obtained results, GR 5 L- cysteine functionalized AuNPs (particle size $30 \mathrm{~nm}$, PDI 0.321, zeta potential $+36.9 \mathrm{mv}$ ) were selected for subsequent examinations and complex formation.

\section{Sample Imaging With TEM (Transmission Electron Microscopy)}

Samples imaging was performed with TEM to investigate the morphology of resultant AuNPs. Figure 2 showed the micrograph of AuNPs. It was illustrated that, the obtained nanoparticles displayed nearly spherical shape, proving that the applied procedure fashioned spherical nanoparticles. The results confirmed the formation of spherical particles

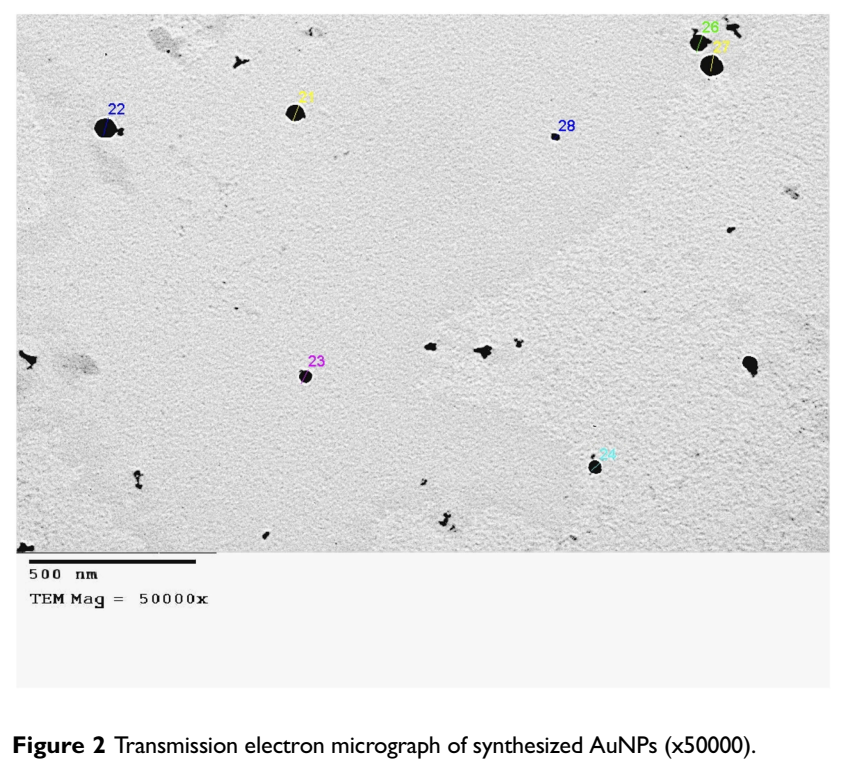


with complete absence of nanorods which usually appear when CTAB is used as surfactant. ${ }^{43}$

\section{Preparation Of Au NPs.p53 Complex Agarose Gel Electrophoresis}

The standard gel retardation assay was used to estimate the ability of AuNPs to condense p53 plasmid DNA molecules. In Figure 3, no unbound pDNA and resistance to migration were evident for complete complexation between p53 and AuNPs at ratio 2/1.

\section{Characterization Of Au NPs.p53 Complex}

The results showed a significant $(P \leq 0.001)$ increase in particle size after complexation. The results revealed that the particle size of the fabricated AuNP-p53 complex was $80 \pm 2 \mathrm{~nm}$ and PDI was 0.252 . Also, the Zeta potential of the complex decreased significantly, shifting to negative charge to $-8 \pm 0.4 \mathrm{mV}$ which may be the effect of the high mass ratio of negatively charged pDNA to positively charged AuNPs. This reality may be beneficial for our goals since the low anionic characteristic of the AuNPsp53 complex decreases the cytotoxic effect. ${ }^{44}$ The TEM micrograph (Figure 4) showed no change in the morphological characteristics of AuNPs after complexation with pDNA with aggregation-free spherical shapes.

\section{In Vitro Transfection Study}

\section{Gene Expression In Normal And Cancerous Lung}

Cells

RT-PCR was used to evaluate the ability of gold nanoparticles to deliver a load of pDNA to cancerous lung cells, A549 cells, after treatment with free pDNA and AuNPs-p53 compared to normal lung cell line (WI-38). Results showed that, the cellular uptake of AuNP-p53 was nearly 9 folds more

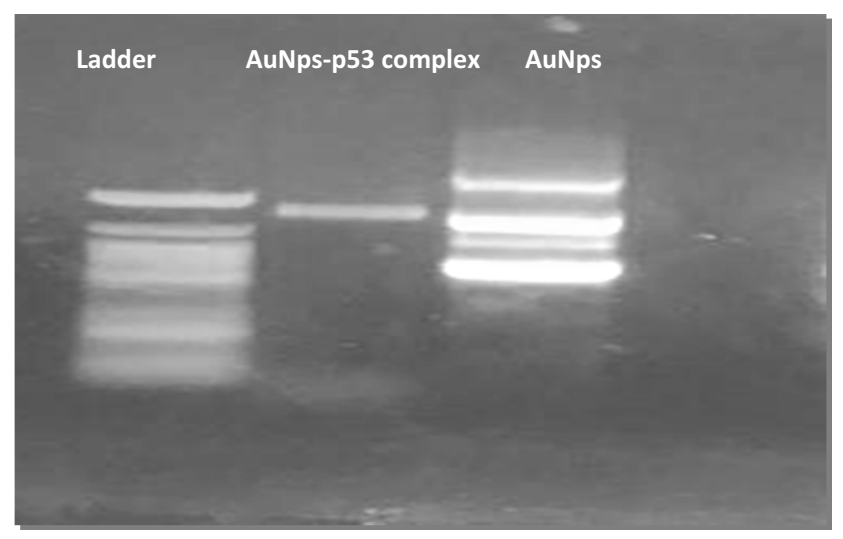

Figure $3 \mathrm{Gel}$ electrophoretic analysis of the free pDNA (ladder), AuNPs.p53 complex, and free AuNPs.

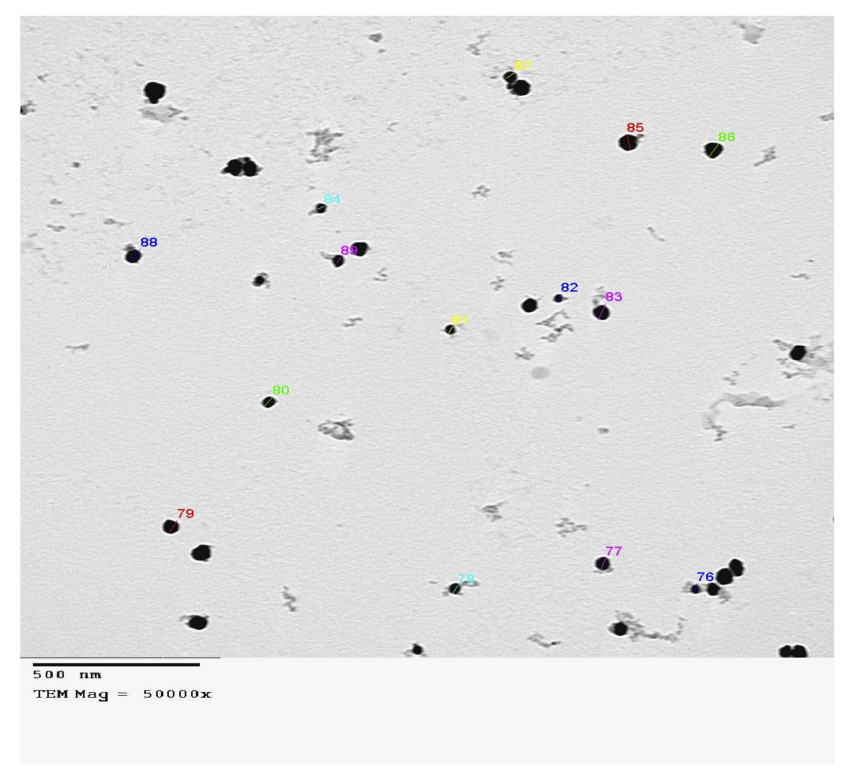

Figure 4 Transmission electron micrograph of synthesized AuNPs-p53 complex (x50000).

than gene expression in normal lung cells (WI 38) and about 5 folds more than gene expression performed by free pDNA (Figure 5). The higher cellular uptake and improved transfection conflict with the hypothesis that the positive surface charge of the pDNA-loaded nanoparticles allows an electrostatic interaction between negatively charged cellular membranes and positively charged nanoparticles. ${ }^{45}$ Moreover, the nanosized particles crossed the cells easily and could deliver the pDNA in appropriate amounts. Results revealed that, p53 gene in A549 was overexpressed; this may be due to the presence of its receptors on the cell's surface, facilitating the receptor-mediated endocytosis. A cancer cell is considered an irreparably DNA damaged cell, and consequently the p53 will stimulate further cell apoptosis sequence. ${ }^{46}$

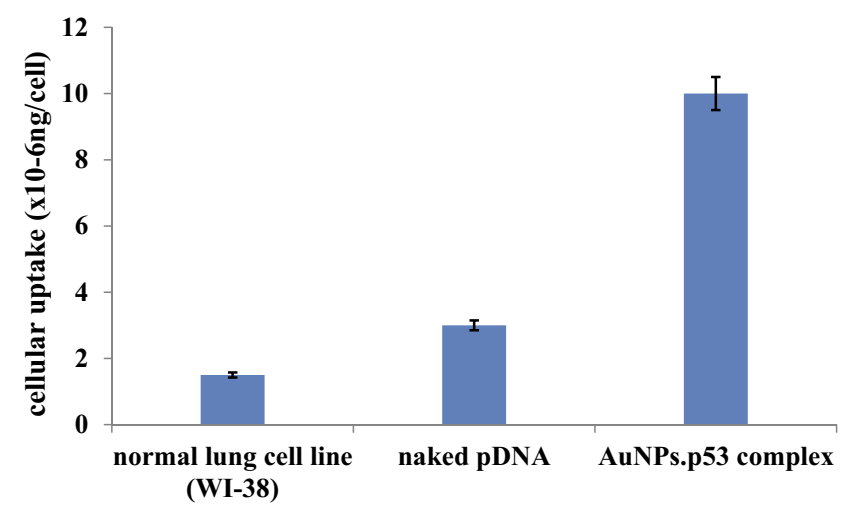

Figure 5 Cellular uptake and expression of free pDNA and AuNP-p53 in lung cancer cells (A549) in comparison to normal gene expression exhibited by healthy lung cells (WI 38). 
As AuNP-p53 complex exhibited a negative charge, this may lead to increased p53 expression inside the cell. ${ }^{47}$ Previous studies have reported cellular uptake of the positively charged particles through macro-pinocytosis. On the other hand, negatively charged particles pass the cell membrane with hitherto unidentified clathrincaveolae independent endocytosis. For example, clathrin-caveolin mediated endocytosis of negatively charged PEG-ylated gold nanoparticles with better rates than positively charged one. ${ }^{48,49}$

Samples were exposed to drastic acidic conditions in endosome followed by slightly alkaline ones in lysosome which resulted in particle damage which potentiated the DNA release. ${ }^{50}$ Other studies reported the cellular uptake of negatively charged particles as a result of random binding of particles with cationic sites on plasma membrane. ${ }^{51}$

\section{In Vitro Cytotoxicity}

A cytotoxicity assay of obtained AuNPs was studied using an MTT assay with a synchronized study on both healthy lung cells (WI38) and cancerous lung cells (A549). In A549 cell line, AuNPs displayed $\mathrm{IC}_{50}$ values of $8.18 \mu \mathrm{g}$ $\mathrm{mL}^{-1}$. On the other hand, in WI38 cell line, the AuNPs

\section{a \\ $\%$ Cell Viability of A549 Cell Line}

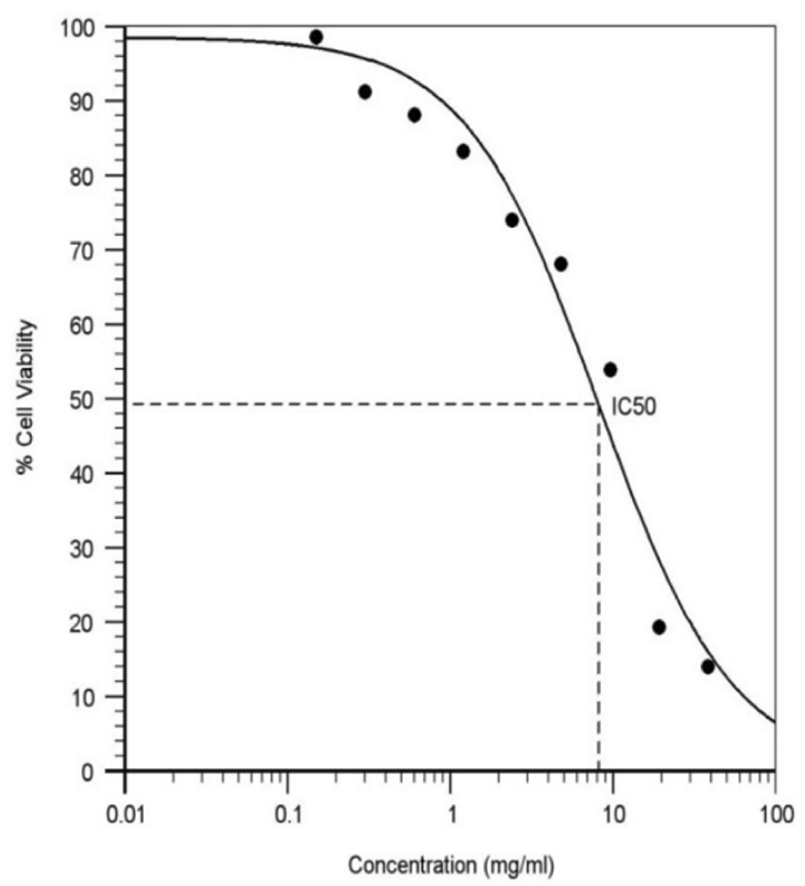

displayed $\mathrm{IC}_{50}$ values of $31.21 \mu \mathrm{g} \mathrm{mL}^{-1}$ (Figure $6 \mathrm{~A}$ and $\mathrm{B})$. According to $\mathrm{IC}_{50}$ values, the results revealed that the resultant AuNPs showed low toxicity against both cell lines used. This result may be due to the small particle size of produced AuNPs. ${ }^{52}$ Moreover, cytotoxicity of AuNP-p53 complex on healthy lung cells (WI38) and cancerous lung cells (A549) was obtained. In A549 cell line, the complex displayed $\mathrm{IC}_{50}$ values of $30.67 \mu \mathrm{g} \mathrm{mL}^{-1}$. On the other hand, in WI38 cell line, the complex displayed $\mathrm{IC}_{50}$ values of $398.46 \mu \mathrm{g} \mathrm{mL}^{-1}$ (Figure 7A and B). According to $\mathrm{IC}_{50}$ values, the results revealed that the resultant AuNPs showed low toxicity against both cell lines used. This suggested the safety of AuNPs as carrier for plasmid $\mathrm{p} 53$.

Previous research studies reported that cytotoxicity of cationic gold nanoparticles is higher than anionic type by 27 fold in three different cancer cell lines. ${ }^{53,54}$ This was explained by two main reasons that may cause this discrepancy, the higher adhesion of cationic gold nanoparticles with negative cell membrane, and the ability of cationic nanogold to significantly disrupt cell membrane compared to anionic one. ${ }^{54,55}$ Membrane disruption with cationic nanogold will permit the exchange of medium between extracellular fluid and cytosol through the newly
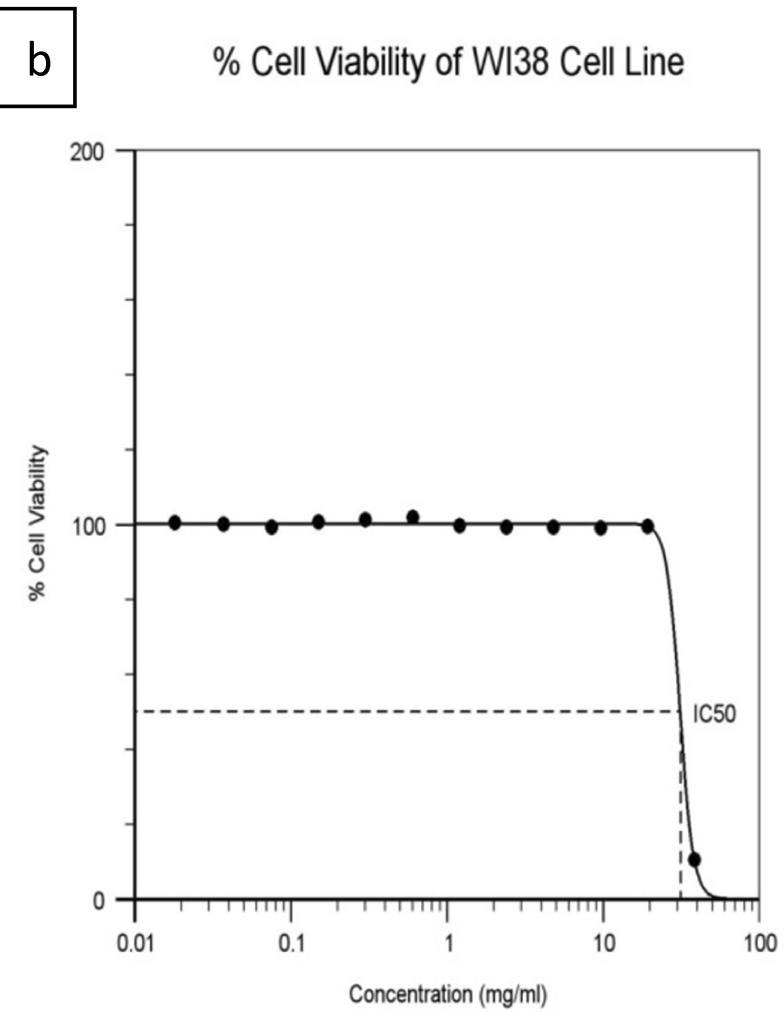

Figure 6 (A) Cell cytotoxicity of A549 cells treated with AuNPs. (B) Viability of WI38 treated with AuNPs. 

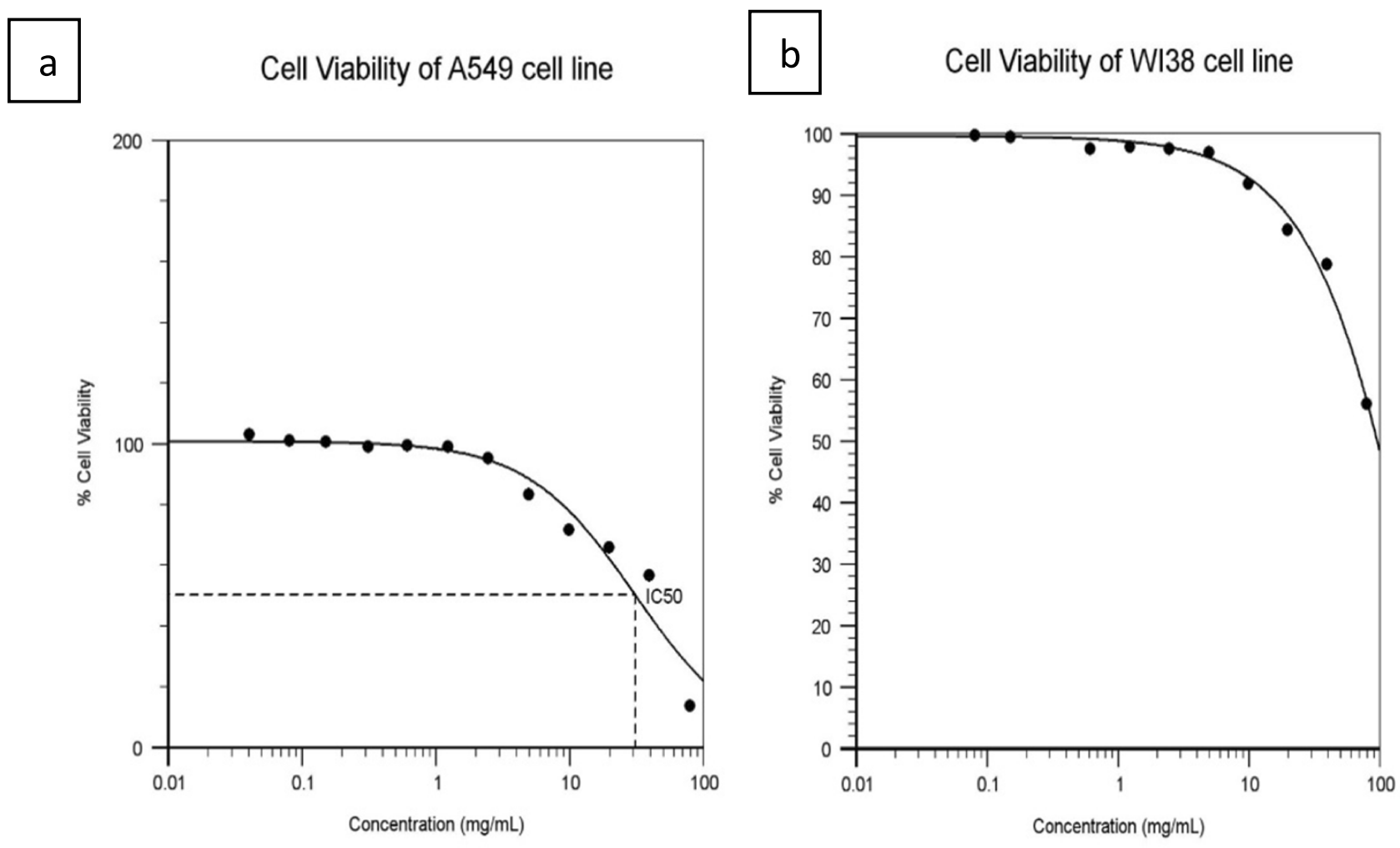

Figure 7 (A) Viability of A549 cells treated with AuNP.p53 complex. (B) Viability of WI38 treated with AuNP.p53 complex.

formed hydrated channel, which may lead to acute cell death due to loss of control of internal contents. ${ }^{55}$ Although anionic nanogold cannot directly affect bilayer integrity, it is capable of changing cell functions by damaging membrane protein function. ${ }^{54}$ The high percentage of cell viability in normal lung cell line (WI 38) proved the safety of L-cysteine methyl ester functionalized AuNPs. Additionally, the apoptotic effect due to expression of gene encoded p53 loaded on AuNPs was only prominent on lung cancer cell line (A549), revealing selectivity and targeting efficiency of anticancer AuNPs-p53 complex.

\section{Conclusion}

The study had succeeded in producing surfactant-free gold nanoparticles and complexed it with plasmid DNA encoded p53 gene using a controlled seed mediated growth approach. The complex formation was confirmed by gel electrophoresis. The RT-PCR proved the expression of $\mathrm{p} 53$ by the fabricated AuNPs-p53 complex. Cytotoxicity studies on both normal and cancer lung cell lines demonstrated that AuNPs were safe and exhibited low cytotoxicity. The high percentage of cell viability in normal lung cell line (WI 38) proved the safety of L-cysteine methyl ester functionalized AuNPs. The apoptotic effect due to expression of gene was only prominent on lung cancer cell line (A549), revealing selectivity and targeting efficiency of anticancer AuNPs-p53 complex. Although there are promising results of AuNPs-based systems for gene delivery, clinical trials are still required.

\section{Disclosure}

The authors report no conflicts of interest in this work.

\section{References}

1. Tseng S-J, Liao Z-X, Kao S-H, et al. Highly specific in vivo gene delivery for p53-mediated apoptosis and genetic photodynamic therapies of tumour. Nat Commun. 2015;6:6456. doi:10.1038/ncomms 7456

2. Prabha S, Sharma B, Labhasetwar V. Inhibition of tumor angiogenesis and growth by nanoparticle-mediated p53 gene therapy in mice. Cancer Gene Ther. 2012;19(8):530. doi:10.1038/cgt.2012.26

3. Senzer N, Nemunaitis J, Nemunaitis D, et al. Phase I study of a systemically delivered p53 nanoparticle in advanced solid tumors. Mol Ther. 2013;21(5):1096-1103. doi:10.1038/mt.2013.32

4. Khoo KH, Verma CS, Lane DP. Drugging the p53 pathway: understanding the route to clinical efficacy. Nat Rev Drug Discov. 2014;13 (3):217. doi: $10.1038 / \mathrm{nrd} 4236$

5. Lane D, Levine A. p53 research: the past thirty years and the next thirty years. Cold Spring Harb Perspect Biol. 2010;2(12):a000893. doi:10.1101/cshperspect.a000893

6. Levav-Cohen Y, Goldberg Z, Tan KH, et al. The P53-MDM2 Loop: A Critical Juncture of Stress Response. Mutant P53 and MDM2 in Cancer. Springer; 2014:161-186. 
7. Duffy MJ, Synnott NC, Crown J. p53 in cancer: ready for therapeutic targeting? Transl Cancer Res. 2016;5(6):627-631. doi:10.21037/tcr

8. Vaseva AV, Moll UM. The mitochondrial p53 pathway. Biochim Biophys Acta Bioenerg. 2009;1787(5):414 420. doi:10.1016/j.bbabio.2008.10.005

9. Muller PA, Vousden KH. p53 mutations in cancer. Nat Cell Biol. 2013;15(1):2-8. doi:10.1038/ncb2641

10. Bieging KT, Mello SS, Attardi LD. Unravelling mechanisms of p53mediated tumour suppression. Nat Rev Cancer. 2014;14(5):359-370. doi: $10.1038 / \mathrm{nrc} 3711$

11. Kruiswijk F, Labuschagne CF, Vousden KH. p53 in survival, death and metabolic health: a lifeguard with a licence to kill. Nat Rev Mol Cell Biol. 2015;16(7):393-405. doi:10.1038/nrm4007

12. Kim -S-S, Rait A, Kim E, et al. A nanoparticle carrying the p53 gene targets tumors including cancer stem cells, sensitizes glioblastoma to chemotherapy and improves survival. ACS Nano. 2014;8(6):54945514. doi: $10.1021 / \mathrm{nn} 5014484$

13. Dong M, Chen J, Zhang J, et al. a chemoenzymatically synthesized cholesterol-g-poly (amine-co-ester)-mediated p53 gene delivery for achieving antitumor efficacy in prostate cancer. Int $J$ Nanomedicine. 2019;14:1149-1161. doi:10.2147/IJN.S191905

14. Tripathi R, Shrivastav A, Shrivastav B. Biogenic gold nanoparticles: as a potential candidate for brain tumor directed drug delivery. Artif Cells Nanomed Biotechnol. 2015;43(5):311-317. doi:10.3109/ 21691401.2014.885445

15. Li J, Liang H, Liu J, Wang Z. Poly (amidoamine)(PAMAM) dendrimer mediated delivery of drug and pDNA/siRNA for cancer therapy. Int $J$ Pharm. 2018;546(1-2):215-225. doi:10.1016/j.ijpharm.2018.05.045

16. Song J, Fang Z, Wang C, et al. Photolabile plasmonic vesicles assembled from amphiphilic gold nanoparticles for remote-controlled traceable drug delivery. Nanoscale. 2013;5(13):5816-5824. doi:10.1039/c3nr01350b

17. Mallick K, Witcomb M. Gold nanoparticles as a delivery vehicle in biomedical applications. Gold Nanoparticles. 2010;225-243.

18. Kumar A, Zhang X, Liang X-J. Gold nanoparticles: emerging paradigm for targeted drug delivery system. Biotechnol Adv. 2013;31 (5):593-606. doi:10.1016/j.biotechadv.2012.10.002

19. Ghosh P, Han G, De M, Kim CK, Rotello VM. Gold nanoparticles in delivery applications. Adv Drug Deliv Rev. 2008;60(11):1307-1315. doi:10.1016/j.addr.2008.03.016

20. Jazayeri MH, Amani H, Pourfatollah AA, Pazoki-Toroudi H, Sedighimoghaddam B. Various methods of gold nanoparticles (GNPs) conjugation to antibodies. Sens Biosensing Res. 2016;9:1722. doi:10.1016/j.sbsr.2016.04.002

21. Guo J, Armstrong MJ, O'Driscoll CM, Holmes JD, Rahme K. Positively charged, surfactant-free gold nanoparticles for nucleic acid delivery. RSC Adv. 2015;5(23):17862-17871. doi:10.1039/C4RA16294C

22. Rahme K, Chen L, Hobbs RG, Morris MA, O'Driscoll C, Holmes JD. PEGylated gold nanoparticles: polymer quantification as a function of PEG lengths and nanoparticle dimensions. RSC Adv. 2013;3 (17):6085-6094. doi:10.1039/C3RA22739A

23. Brown KR, Lyon LA, Fox AP, Reiss BD, Natan MJ. Hydroxylamine seeding of colloidal Au nanoparticles. 3. controlled formation of conductive Au films. Chem Mater. 2000;12(2):314-323. doi:10.1021/ cm980066h

24. Abrica-González P, Zamora-Justo JA, Sotelo-López A, et al. Gold nanoparticles with chitosan, $\mathrm{N}$-acylated chitosan, and chitosan oligosaccharide as DNA carriers. Nanoscale Res Lett. 2019;14(1):258. doi:10.1186/s11671-019-3083-y

25. Loughery J, Cox M, Smith LM, Meek DW. Critical role for p53serine 15 phosphorylation in stimulating transactivation at p53responsive promoters. Nucleic Acids Res. 2014;42(12):7666-7680. doi:10.1093/nar/gku501

26. Lotfipour F, Hallaj-Nezhadi S, Valizadeh H, et al. Preparation of chitosan-plasmid DNA nanoparticles encoding interleukin-12 and their expression in CT-26 colon carcinoma cells. J Pharm Pharm Sci. 2011;14(2):181-195. doi:10.18433/J3TP4T
27. El-Leithy ES, Hassan SA, Abdel-Rashid RS. Tamoxifen citrate/coenzyme Q10 as smart nanocarriers bitherapy for breast cancer: cytotoxicity, genotoxicity, and antioxidant activity. J Drug Deliv Sci Technol. 2019;51:36-44. doi:10.1016/j.jddst.2019.02.010

28. Huang L, Yan H, Jiang X, et al. Reference gene selection for quantitative real-time reverse-transcriptase PCR in orchardgrass subjected to various abiotic stresses. Gene. 2014;553(2):158-165. doi:10.1016/j. gene.2014.10.017

29. Chen KG, Valencia JC, Gillet JP, Hearing VJ, Gottesman MM. Involvement of $\mathrm{ABC}$ transporters in melanogenesis and the development of multidrug resistance of melanoma. Pigment Cell Melanoma Res. 2009;22(6):740-749. doi:10.1111/j.1755-148X.2009.00630.x

30. Yasun E, Li C, Barut I, et al. BSA modification to reduce CTAB induced nonspecificity and cytotoxicity of aptamer-conjugated gold nanorods. Nanoscale. 2015;7(22):10240-10248. doi:10.1039/c5nr01704a

31. Ngumbi PK, Mugo SW, Ngaruiya JM. Determination of gold nanoparticles sizes via surface plasmon resonance. IOSR J Appl Chem. 2018;11(7Ver. I):25-29.

32. Zuber A, Purdey M, Schartner E, et al. Detection of gold nanoparticles with different sizes using absorption and fluorescence based method. Sens Actuators B Chem. 2016;227:117-127. doi:10.1016/j.snb.2015.12.044

33. Ziegler C, Eychmüller A. Seeded growth synthesis of uniform gold nanoparticles with diameters of $15-300 \mathrm{~nm}$. J Phys Chem $C$. 2011;115(11):4502-4506. doi:10.1021/jp1106982

34. Martínez J, Chequer N, González J, Cordova T. Alternative methodology for gold nanoparticles diameter characterization using PCA technique and UV-VIS spectrophotometry. Nanosci Nanotechnol. 2012;2(6):184-189. doi:10.5923/j.nn.20120206.06

35. Jongjinakool S, Palasak K, Bousod N, Teepoo S. Gold nanoparticlesbased colorimetric sensor for cysteine detection. Energy Procedia. 2014;56:10-18. doi:10.1016/j.egypro.2014.07.126

36. Piella J, Bastús NG, Puntes V. Size-controlled synthesis of sub-10nanometer citrate-stabilized gold nanoparticles and related optical properties. Chem Mater. 2016;28(4):1066-1075. doi:10.1021/acs. chemmater.5b04406

37. Xia H, Bai S, Hartmann J, Wang D. Synthesis of monodisperse quasispherical gold nanoparticles in water via silver (I)-assisted citrate reduction. Langmuir. 2009;26(5):3585-3589. doi:10.1021/la902987w

38. Huang Y-J, Shiau A-L, Chen S-Y, et al. Multivalent structure of galectin-1-nanogold complex serves as potential therapeutics for rheumatoid arthritis by enhancing receptor clustering. Eur Cell Mater. 2012;23:170-181.

39. Oh E, Delehanty JB, Sapsford KE, et al. Cellular uptake and fate of PEGylated gold nanoparticles is dependent on both cell-penetration peptides and particle size. ACS Nano. 2011;5(8):6434-6448. doi:10.1021/ nn201624c

40. Shan Y, Ma S, Nie L, et al. Size-dependent endocytosis of single gold nanoparticles. Chem Commun. 2011;47(28):8091-8093. doi:10.1039/ c1cc11453k

41. Elbakry A, Wurster EC, Zaky A, et al. Layer-by-layer coated gold nanoparticles: size-dependent delivery of DNA into cells. Small. 2012;8(24):3847-3856. doi:10.1002/smll.201201112

42. Liu X, Huang N, Li H, Jin Q, Ji J. Surface and size effects on cell interaction of gold nanoparticles with both phagocytic and nonphagocytic cells. Langmuir. 2013;29(29):9138-9148. doi:10.1021/la401556k

43. Ahmad I, Derkink F, Boulogne T, et al. Self-assembly and wetting properties of gold nanorod-CTAB molecules on HOPG. Beilstein J Nanotechnol. 2019;10(1):696-705. doi:10.3762/bjnano.10.69

44. Martínez-Negro M, Guerrero-Martínez A, García-Río L, et al. Multidisciplinary approach to the transfection of plasmid DNA by a nonviral nanocarrier based on a gemini-bolaamphiphilic hybrid lipid. ACS Omega. 2018;3(1):208-217. doi:10.1021/acsomega.7b01657

45. Hashem FM, Nasr M, Khairy A, Alqurshi A. In vitro cytotoxicity and transfection efficiency of pDNA encoded p53 gene-loaded chitosansodium deoxycholate nanoparticles. Int J Nanomedicine. 2019;14:41234131. doi:10.2147/IJN.S205324 
46. Brannon-Peppas L, Blanchette JO. Nanoparticle and targeted systems for cancer therapy. Adv Drug Deliv Rev. 2012;64:206-212. doi:10.1016/j.addr.2012.09.033

47. Schaeublin NM, Braydich-Stolle LK, Schrand AM, et al. Surface charge of gold nanoparticles mediates mechanism of toxicity. Nanoscale. 2011;3(2):410-420. doi:10.1039/c0nr00478b

48. Zhao F, Zhao Y, Liu Y, Chang X, Chen C, Zhao Y. Cellular uptake, intracellular trafficking, and cytotoxicity of nanomaterials. Small. 2011;7(10):1322-1337. doi:10.1002/smll.201100001

49. Harush-Frenkel O, Rozentur E, Benita S, Altschuler Y. Surface charge of nanoparticles determines their endocytic and transcytotic pathway in polarized MDCK cells. Biomacromolecules. 2008;9 (2):435-443. doi:10.1021/bm700535p

50. Zhang LW, Monteiro-Riviere NA. Mechanisms of quantum dot nanoparticle cellular uptake. Toxicol Sci. 2009;110(1):138-155. doi:10.1093/ toxsci/kfp087
51. Salatin S, Yari Khosroushahi A. Overviews on the cellular uptake mechanism of polysaccharide colloidal nanoparticles. J Cell Mol Med. 2017;21(9):1668-1686. doi:10.1111/jcmm.13110

52. Cheng L-C, Jiang X, Wang J, Chen C, Liu R-S. Nano-bio effects: interaction of nanomaterials with cells. Nanoscale. 2013;5(9):35473569. doi:10.1039/c3nr34276j

53. Hauck TS, Ghazani AA, Chan WC. Assessing the effect of surface chemistry on gold nanorod uptake, toxicity, and gene expression in mammalian cells. Small. 2008;4(1):153-159. doi:10.1002/smll. 200700217

54. Lin J, Zhang H, Chen Z, Zheng Y. Penetration of lipid membranes by gold nanoparticles: insights into cellular uptake, cytotoxicity, and their relationship. ACS Nano. 2010;4(9):5421-5429. doi:10.1021/ nn1010792

55. Verma A, Stellacci F. Effect of surface properties on nanoparticle-cell interactions. Small. 2010;6(1):12-21. doi:10.1002/smll.200901158

\section{Publish your work in this journal}

The International Journal of Nanomedicine is an international, peerreviewed journal focusing on the application of nanotechnology in diagnostics, therapeutics, and drug delivery systems throughout the biomedical field. This journal is indexed on PubMed Central, MedLine, CAS, SciSearch ${ }^{\mathbb{R}}$, Current Contents ${ }^{\mathbb{R}} /$ Clinical Medicine, $^{-}$
Journal Citation Reports/Science Edition, EMBase, Scopus and the Elsevier Bibliographic databases. The manuscript management system is completely online and includes a very quick and fair peer-review system, which is all easy to use. Visit http://www.dovepress.com/ testimonials.php to read real quotes from published authors. 